\title{
Lactose absorption in patients with glucose 6-phosphate dehydrogenase deficiency with and without favism
}

\author{
T Meloni, C Colombo, A Ogana, M C Mannazzu, G F Meloni
}

\begin{abstract}
Background-It has recently been suggested that primary lactase deficiency might have been selected for by malaria, as has been previously shown to occur for thalasaemia and glucose 6-phosphate dehydrogenase (G6PD) deficiency.

Aims-To test this hypothesis, the prevalence of primary lactase deficiency in G6PD deficient subjects and in controls from the area of Sassari (Northern Sardinia) was determined, which in the past was characterised by an intermediate malarial endemicity.
\end{abstract}

Subjects-70 adult subjects with G6PD deficiency, 34 of whom had a past history of favism, and 50 age matched control subjects.

Methods-The capacity to absorb lactose was assessed by measuring breath hydrogen production after oral administration of lactose $(50 \mathrm{~g})$ by a gas chromatographic method.

Results-Twenty per cent of G6PD deficient subjects with a positive history of favism and $22 \%$ of G6PD deficient subjects without a positive history of favism were lactose absorbers compared with 14\% lactose absorbers in the control group. The differences were not statistically significant.

Conclusions-These data show that the prevalence of primary lactase deficiency in the area of Sassari is relatively high, but comparable to that seen in the adult population from another area of southern Italy (Naples) where malaria was less endemic.

(Gut 1996; 39: 210-213)

Keywords: primary lactase deficiency, glucose 6-phosphate dehydrogenase deficiency, favism, malaria.

Department of

Paediatrics and

Neonatology,

University of Sassari,

Italy

T Meloni

C Colombo

A Ogana

M C Mannazzu

G F Meloni

Correspondence to:

Dr T Meloni, Department of

Paediatrics, University of

Sassari, Viale San Pietro 12,

01700 Sassari, Italy.

Accepted for publication

21 March 1996 adult lactase deficiency phenotype). In othe healthy humans with a long history of milk drinking (people from northwest Europe and Afro-Arabian nomads) lactase activity is maintained at a level similar to that found in infants (lactase persistence phenotype). An autosomal gene is believed to be responsible for the two phenotypes, with a dominant lactase persistence allele and a recessive lactase restriction allele.

The distribution of the lactase phenotypes in human populations is highly variable, but the geographical areas where lactase deficiency or persistence predominate are now well mapped. ${ }^{2}$

The finding that lactase deficiency predominates in those areas where malaria was endemic and where thalassaemia, glucose 6-phosphate dehydrogenase (G6PD) deficiency and sickle cell disease are very frequent, has recently suggested a challenging hypothesis. ${ }^{3}$ Similar to these red cell genetic defects, which are believed to have been selected for by malaria, ${ }^{4}$ primary adult lactase deficiency might also have resulted from a selection for a mutant lactase restriction phenotype by malaria, starting in prehistoric times.

The hypothesis is based on the finding that malaria parasites need flavins for efficient multiplication within red blood cells and a good source of flavins in human nutrition is milk. In subjects with lactose intolerance, consumption of milk is substantially reduced due to development of intestinal problems related to lactose malabsorption. They may therefore become riboflavin deficient and thus more resistant to malaria. ${ }^{56}$ This proposed mechanism is interesting, although the facts that most malaria mortality in Africa occurs in the age group in which lactase is still expressed, and that the frequency of clinical malaria declines very rapidly with age are not in agreement with this hypothesis. ${ }^{7}$

Until 1946 Sardinia was among the areas in Europe with the highest occurrence of malaria, and its inhabitants have a high incidence of G6PD deficiency and thalassaemia. ${ }^{8}$ They may therefore represent an ideal population to assess correlations between all these conditions and primary lactase deficiency.

We have previously reported that intestinal $\beta$-glucosidase activity in normal and G6PD deficient children with or without favism are similar ${ }^{9}$; although this is considered a reliable means for the diagnosis of disaccharidase deficiency, it cannot be excluded that lactase activity might have decreased later in life in these subjects who were younger than 12 years of age.

We have therefore studied the capacity to absorb lactose by measuring breath hydrogen production after oral administration of lactose in adult subjects with G6PD deficiency with and without a history of favism and in controls, all from Sassari or from the surrounding areas, 
TABLE I Characteristics of the subjects enrolled in the study

\begin{tabular}{llll}
\hline & Controls & G6PD deficient & $\begin{array}{l}\text { G6PD deficient } \\
\text { with favism }\end{array}$ \\
\hline Number & 50 & 36 & 34 \\
Sex (M/F) & $25 / 25$ & $36 / 0$ & $34 / 0$ \\
Age (y) (mean (SD), range) & $41 \cdot 0(7 \cdot 5)(19-50)$ & $22 \cdot 2(4 \cdot 9)(19-49)$ & $23 \cdot 1(3 \cdot 5)(19-29)$ \\
Milk drinking* (\%) & $60 \cdot 0$ & $63 \cdot 9$ & $64 \cdot 7$ \\
\hline
\end{tabular}

*Average milk consumption: $250 \mathrm{ml} /$ day, average consumption of dairy products: $200 \mathrm{~g} /$ day

which in the past were characterised by an intermediate malarial endemicity.

\section{Methods}

Subjects

We studied 70 G6PD deficient male subjects, 34 of whom had a past history of favism and had been admitted during childhood to the Department of Paediatrics of the University of Sassari; 50 normal adults matched for age served as control group. Table I gives the demographic characteristics of the subjects. A detailed history of milk drinking habits was obtained from patients and controls.

G6PD activity in men was assayed on erythrocytes purified by cellulose column filtration according to the method of Battistuzzi et al. ${ }^{10}$ Although hemizygous males and homozygous females are accurately detected by this method, up to $30 \%$ of heterozygous females are missed, because of the presence of a double red blood cell population, one with G6PD activity, and the other with no activity detectable. In these subjects G6PD activity is comparable to the lowest levels observed in normal males. Therefore, in women, enzyme activity was determined using the technique of 2-deoxy glucose-6-phosphate (2-dG6P) utilisation in mononuclear cells: this method accurately identifies the degree of G6PD mosaicism in various hemopoietic cell populations. ${ }^{11}$

In all subjects, in the morning, after an overnight fasting period, lactose $(50 \mathrm{~g})$ was given orally as $15 \%$ water solution; expired air samples were obtained at baseline and at 30

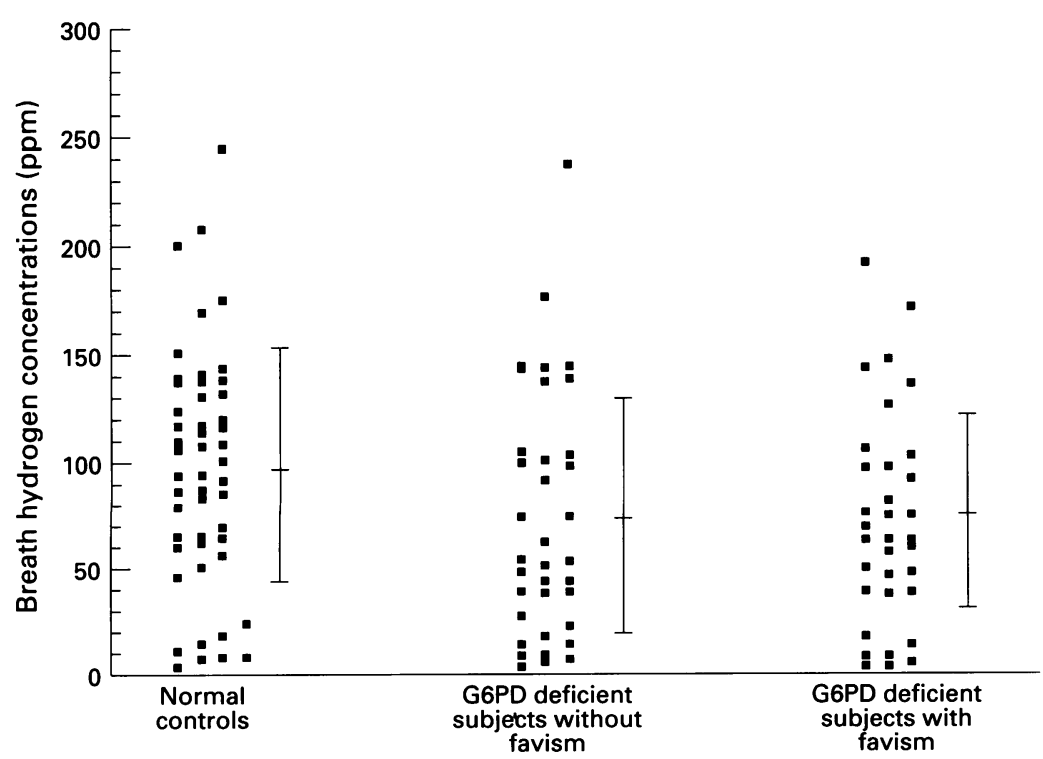

Breath hydrogen concentrations (ppm) in healthy controls and in G6PD deficient subjects with and without favism. minute intervals for 240 minutes after lactose administration. ${ }^{12}$ Hydrogen concentrations were determined with a gas chromatographic method, using a 121 Quinton gas chromatograph. According to Flatz et al, ${ }^{13}$ lactose malabsorption was diagnosed if the maximum increase in hydrogen in the expired air was greater than $20 \mathrm{ppm}$. During the breath test and for at least three hours after its completion, all subjects were specifically observed for the development of abdominal symptoms resulting from lactose malabsorption (flatulence, abdominal distension, abdominal pain, and diarrhoea).

Statistical analysis

Analysis of variance was used to compare differences among groups.

The prevalence of lactose absorbers among the two groups of G6PD deficient subjects was compared with that found in the control group by means of the $\chi^{2}$ test.

\section{Results}

In the two groups of G6PD deficient subjects (with and without a past history of favism), G6PD activity was very near $0 \mathrm{UI} / \mathrm{g} \mathrm{Hb}$.

With regard to enzyme activity in the control group, in men it was found to range between 4.98 and $10.2 \mathrm{UI} / \mathrm{g} \mathrm{Hb}$ (normal values: 6.92 $(2 \cdot 10) \mathrm{UI} / \mathrm{g} \mathrm{Hb})$, whereas in women a mean activity of $6.51 \mathrm{UI} / \mathrm{g} \mathrm{Hb}$ was detected (range 4.12-9.09 UI/g Hb).

As G6PD activity in heterozygous women is comparable to the lowest values seen in normal men, in women controls 2-dG6P utilisation in mononuclear cells was also determined. ${ }^{11}$ By this technique the percentage of 2-dG6P utilisation is higher than $30 \%$ in homozygous, ranges from 7 to $28 \%$ in heterozygous, and is lower than $6 \%$ in normal subjects; in our female controls it ranged from $3 \cdot 2 \%$ to $5 \cdot 4 \%$, indicating that these subjects were not G6PD deficient.

Maximum hydrogen concentration in the expired air after oral lactose administration in G6PD deficient subjects with and without favism and in normal controls coming from the same geographical area are shown in the Figure: differences among groups were not significant.

Twenty per cent of G6PD deficient subjects with a positive history of favism and $22 \%$ of G6PD deficient subjects without a positive history of favism were lactose absorbers compared with $14 \%$ of lactose absorbers in the control group.

These differences were not statistically significant, as there was no significant difference in the maximum hydrogen concentrations achieved by lactose absorbers and by lactose malabsorbers in the three groups (Table II).

Symptoms related to lactose malabsorption, such as flatulence, borborygmus, abdominal distension, pain, and diarrhoea, were reported from none of the lactose absorbers in the three groups and from $37 \cdot 2 \%, 32 \cdot 1 \%$, and $29 \cdot 6 \%$ of lactose malabsorbers in controls and in G6PD 
TABLE II Breath hydrogen concentration after oral lactose tolerance test in lactose absorbers and lactose malabsorbers of the three groups of subjects (mean values $(S D))^{*}$

\begin{tabular}{|c|c|c|c|c|}
\hline & \multicolumn{2}{|c|}{ Lactose absorbers $\left(\mathrm{H}_{2}<20 \mathrm{ppm}\right)$} & \multicolumn{2}{|c|}{ Lactose malabsorbers $\left(\mathrm{H}_{2}>20 \mathrm{ppm}\right)$} \\
\hline & $\begin{array}{l}\text { Number } \\
\text { of cases } \\
(\%)\end{array}$ & $\begin{array}{l}\text { Maximum breath } \\
\mathrm{H}_{2} \text { concentrations } \\
(\mathrm{ppm})\end{array}$ & $\begin{array}{l}\text { Number } \\
\text { of cases } \\
(\%)\end{array}$ & $\begin{array}{l}\text { Maximum breath } \\
\mathrm{H}_{2} \text { concentrations } \\
\text { (ppm) }\end{array}$ \\
\hline $\begin{array}{l}\text { Controls }(n=50) \\
\text { G6PD without favism }(n=36) \\
\text { G6PD with favism }(n=34)\end{array}$ & $\begin{array}{l}7(14 \cdot 0) \\
8(22 \cdot 2) \\
7(20 \cdot 6)\end{array}$ & $\begin{array}{r}9 \cdot 9(4 \cdot 6) \\
10 \cdot 7(4 \cdot 5) \\
10 \cdot 1(4 \cdot 8)\end{array}$ & $\begin{array}{l}43(86) \\
28(77 \cdot 8) \\
27(79 \cdot 4)\end{array}$ & $\begin{array}{r}96 \cdot 6(49 \cdot 7) \\
88 \cdot 5(40 \cdot 4) \\
113 \cdot 8(49 \cdot 9)\end{array}$ \\
\hline
\end{tabular}

${ }^{\star} p$ Values were not significant for any of these groups.

deficient subjects with and without favism, respectively.

\section{Discussion}

Glucose-6-phosphate dehydrogenase deficiency is the most common enzymatic defect of red blood cells; it is estimated to affect 400 million people worldwide. ${ }^{14}$ In Sardinia the overall prevalence is high, with marked differences in different parts of the island. The prevalence rate is higher on the west coast ( $35 \%$ in men), where malaria was endemic for centuries, than in the mountains ( $4 \%$ in men), where there was little or no malaria. ${ }^{8}$ In the area of Sassari, a $7 \cdot 29 \%$ prevalence of G6PD deficient subjects ${ }^{15}$ as well as an intermediate malarial endemicity have been reported. Indeed, a positive correlation between past malarial incidence and prevalence of G6PD deficiency and $\beta$-thalassaemia has been reported by Siniscalco et al, suggesting selection of these genetic red blood cell defects by malaria. $^{8}$

The commonest clinical manifestations of G6PD deficiency are neonatal jaundice and acute haemolytic anaemia, which can be triggered by several drugs, bacterial and viral infections, and by the ingestion of fava beans (favism). A small proportion of G6PD deficient subjects have a chronic non-spherocytic haemolytic anaemia, which may be quite severe. ${ }^{14}$

Not all G6PD deficient subjects are sensitive to fava beans, suggesting that other environmental or genetically determined factors, or both, in addition to G6PD deficiency may be required for the development of favism. Mendelian segregation of an autosomal recessive gene, which in the heterozygous state would increase the susceptibility to favism of G6PD deficient subjects has been suggested by the observation of familial aggregation of cases ${ }^{16}$; in addition the amount and form in which the bean is eaten and the season of consumption may be important environmental factors.

Susceptible people do not seem to differ in their capacity to digest and absorb fava beans, although a different breakdown of the metabolically inactive glycosides present in fava beans to the active metabolites that trigger the haemolytic crises (divicine and isouramil) by intestinal $\beta$-glucosidase has been postulated. However, no difference has been observed in $\beta$-glucosidase activity in small intestinal biopsy specimens of G6PD deficient children with and without favism when compared with normal controls. ${ }^{9}$
As an initial test of the recently formulated hypothesis that primary lactase deficiency might have been selected for by malaria, ${ }^{3}$ we have determined the prevalence of lactose malabsorption in the population of the Sassari area.

We found that the prevalence of primary lactase deficiency in this area is relatively high ( $86 \%$ of cases), while the frequency of lactose absorbers (and therefore of persistent lactase activity) is comparable with that seen in the adult population of another geographical area in southern Italy (Naples), ${ }^{12}$ where malaria was less endemic. In addition, we did not find a significant difference in prevalence of lactose malabsorption between normal and G6PD deficient subjects.

In contrast, data from two other Italian studies are consistent with a substantially lower prevalence of primary lactase deficiency in northern Italy (44\% and 49\%). ${ }^{17} 18$ These differences may relate to different patterns of milk consumption over a long historical period, ${ }^{2}$ although they may also relate to malaria endemicity.

To investigate this problem further, we are presently looking for the existence of a correlation between prevalence rates of primary lactase deficiency and G6PD deficiency in the population of three Sardinian villages (Cabras, Fonni, and Lodé), which differ remarkably with respect to history of endemic malaria, prevalence of $\alpha$ and $\beta$ thalassaemias and G6PD deficiency and history of milk drinking habits.

1 Semenza G, Auricchio S. Small-intestinal disaccharidases. In: Scriver ChR, Beaudet AL, Sly WS, Valle D, eds. The metabolic and molecular bases of inherited disease. New York: McGraw-Hill, 1995: 4451-82.

2 Simoons FJ. The geographic hypothesis and lactose malabsorption. A weighing of the evidence. Dig Dis 1978; 23 : 963-80.

3 Anderson B, Vullo C. Did malaria select for primary adult lactase deficiency? Gut 1994; 35: 1487-9.

4 Nagel RL, Roth EF. Malaria and red cell genetic defects. Blood 1989; 74: 1213-21.

5 Das BS, Das DB, Satpathy RN, Patnaik JK, Bose TK Riboflavin deficiency and severity of malaria. Eur $\mathcal{f}$ Clin Nutr 1988; 42: 277-83.

6 Zhang Y, Konig I, Schirmer RH. Glutathione reductasedeficient erythrocytes as host cells of malarial parasites. Biochem Pharmacol 1988; 37: 861-5.

7 Alonso PL, Smith T, Tanner M. Efficacy of SPf66 vaccine against Plasmodium falciparum malaria in children. (Letter, Authors' reply). Lancet 1995; 345: 135.

8 Siniscalco M, Bernini L, Latte B, Motulsky AG. Favism and thalassemia in Sardinia and their relationship to malaria. thalassemia in Sardinia and th

9 Mareni C, Repetto L, Forteleoni G, Meloni T, Gaetani GF Favism: looking for an autosomal gene associated with Favism: looking for an autosomal gene associated with
glucose-6-phosphate dehydrogenase deficiency. $₹ \mathrm{Med}$ glucose-6-phosphate dehyc

10 Battistuzzi G, Esan GJF, Fasuan FA, Modiano G, Luzzato L. Comparison of $\mathrm{GdA}$ and $\mathrm{GdB}$ activities in Nigerians. A study of the variation of the G6PD activity. Am $\mathcal{F ~ H u m}$ Genet 1977; 29: 31-6.

11 Ferraris AM, Giuntini P, Galiano S, Gaetani GF. 2-deoxy glucose-6-phosphate dehydrogenase utilization in the 
study of glucose-6-phosphate dehydrogenase mosaicism Am ₹ Hum Genet 1981; 33: 307-13.

12 Rinaldi E, Albini L, Costagliola C, De Rosa G, Auricchio G, De Vizia B, et al. High frequency of lactose absorber among adults with idiopathic senile and presenile cataract in a population with a high prevalence of primary adult lactose malabsorption. Lancet 1984; i: 355-7.

13 Flatz G, Kuhnau W, Naftali D. Breath hydrogen test for lactose absorption capacity: importance of timing of hydroting hydrogen concentration. Am fClin Nutr 1984; 39: 752-5.

14 Luzzatto L, Mehta A. Glucose-6-phosphate dehydrogenase deficiency. In: Scriver ChR, Beaudet AL, Sly WS, Valle D, eds. The metabolic and molecular bases of inherited disease. 7th ed. New York: McGraw-Hill, 1995: 3367-98.
15 Meloni T, Forteleoni G, Ena F, Meloni GF. Glucose-6phosphate dehydrogenase deficiency and bacterial infections in northern Sardinia. F Pediatr 1991; 118: 909-11.

16 Stamatoyannopoulos G, Fraser GR, Motulsky AG, Fessa $\mathrm{P}$, Akrivakis A, Papayannopoulou T. On the familia predisposition to favism. Am f Hum Genet 1966; 18: 253-63.

17 Spinelli D, Vota MG, Formenti F, Accetta S, Careddu P, Roggero $\mathrm{P}$, et al. Idiopathic presenile and senile cataract formation and changes in lactase activity. Fortschr Ophthalmol 1987; 84: 666-8.

18 Burgio GR, Flatz C, Barbera C, Patane R, Boner A Cajozzo C, et al. Prevalence of primary adult lactose malabsorption and awareness of milk intolerance in Italy. $\mathrm{Am}$ $\mathfrak{f}$ Clin Nutr 1984; 39: 100 . 